\title{
Parental and Teachers' Anxiety regarding Actual Learning through Online Teaching-Learning among School Children during COVID-19 Pandemic Lockdown
}

\section{Preeti Chandel $^{1}$ and Amiteshwar Ratra ${ }^{2^{*}}$}

\author{
${ }^{1}$ Research Scholar, STRIDE, Indira Gandhi National Open University, New Delhi, India \\ ${ }^{2}$ Associate Professor, STRIDE, Indira Gandhi National Open University, New Delhi, India \\ *Corresponding author: amiteshwar@ignou.ac.in
}

Received: 24 Oct., 2020

Revised: 22 Nov., 2020

Accepted: 15 Dec., 2020

\begin{abstract}
The purpose of this study was to examine parental and teachers' anxiety regarding actual learning getting transacted through online teaching-learning mode among school children during COVID-19 pandemic. COVID-19 pandemic brought about an immediate closedown of schools. In effect, it was not closedown; rather, it was digitalization of education. Conventional school teaching was changed into online platform. School education was not stopped but it continued with the help of different technology in online or distance education forms. However, there have been apprehensions among parents and teachers alike regarding how much the school children are actually learning through this novel online teaching learning mode. To examine this aspect, the study was conducted with parents and teachers as participants. The sample was identified using the snowball method for selecting the respondents, and focussed interview method was used for data collection. Data was analysed using thematic grouping of responses. A total 53 respondents were selected of which 25 respondents were teachers and 28 respondents were parents from Himachal Pradesh, India. In-depth interview was held telephonically after developing rapport, and fixing up interview time. Both parents and teachers reported that sudden transfer of school education to home created problems for both teachers as well as parents. Teachers were expected to teach using online mode and learn technology for teaching-learning on the job. Parents of school children were expected to take up the role of a teacher at home, provide internet network,
\end{abstract}

How to cite this article: Chandel, P. and Ratra, A. (2020). Parental and Teachers' Anxiety regarding Actual Learning through Online Teaching-Learning among School Children during COVID-19 Pandemic Lockdown. Learning Community, 11(2): 79-90. 
provide devices for online education from home and learn their usage. All the teachers and parents reported concern regarding the school children's actual learning through the online teaching-learning process. It was reported that in this crucial time, where teachers had not been able to teach in actual classroom set-up, and parents were involved in teaching children as suggested by teachers in the online class, some of the parents reported that they felt incompetent to teach their child; especially the older children. A few parents also reported that teaching children and doing their own job in work from home mode resulted at times into a lot of stress for themselves. Both parents and teachers reported feeling anxiety and concern about students' actual learning. This paper concludes with suggestions to improve actual learning among school children and methods to reduce parental and teachers' anxiety.

Keywords: Parental anxiety, teachers' anxiety, online education, distance education, technology, perception, COVID-19, school education, school children

COVID-19 was declared as a global pandemic on 12 ${ }^{\text {th }}$ March 2020 by World Health Organization (WHO) subsequent to the appearance of COVID-19 coronavirus infection in December, 2019 at Wuhan, China [1]. World Health Organization reported that as people who suffer from COVID-19 breathe out or cough, the tiny droplets contain the virus. These droplets may create infection by penetrating into someone's mouth or nose. This disease spreads through direct contact with someone who has the infection or touched the surface [2]. All the countries declared lockdown due to COVID-19, to stop spread of this virus, and declared social distancing as mandatory, resulting in close down of all non-essential services. Trades, industries, factories, institutions, schools, colleges were closed and the world came to a standstill. Everyone was told to stay indoors and follow social distancing. All over the world, to avoid spread of coronavirus and with the close down of conventional education system, all the processes of teaching-learning were through online mode. Distance education took the place of face-to-face teaching-learning as an option to continuity of education after lockdown of schools and students experiencing a loss of learning during lockdown [3].

Education is an important sector in any country and is a major investment in the growth of the nation. Education means a type of self-development that will be passed on from one generation to the next in the form of learning, information, skills and behaviours. Education is one of the keys to success for humans. Education plays an important role in every aspect like economic, social, cultural or moral growth. Education is the platform which manipulates the manpower required for national growth. Education also increases the awareness of individuals and promotes national growth. In the form of telephone, aeroplane, machine and cell phone, and in the form of uncountable other innovations and discoveries, the pages of history are full of such inspiring transformations brought about by the positive impacts of education on the lives of individuals. We are living in a forward-thinking and creative community. Creativity, information synthesis, analysis and critical thinking are the demands of the era. For the national development of the country, students need to be familiarised with technology and modern living methodologies. Thus, education plays a vital role in the development of any nation 
[4]. Without education, no country achieves progress. The closure of all educational institutes due to rapid spread of coronavirus affected the world's entire educational sector. It was estimated that in 188 countries more than 91 percent of the world's students were out of school due to school closure [5]. In many countries, including India, in the place of face-to-face education in a classroom, distance or online education were resorted to as seemingly the only alternative viable in the pandemic scenario to ensure continuity of education. Distance or online education means we get education from distance and instruction is imparted via internet to students using the computer or any other android or iOS mobile set, using email, web, etc.

Keeping the above in view, the present study was undertaken with the following objectives:

To ascertain the need for online teaching-learning process,

To examine teachers' anxiety regarding the actual learning that takes through online teachinglearning process among school children,

To examine parental anxiety regarding the actual learning that takes through online teachinglearning process among school children,

To determine the felt constraints in the online teaching-learning process with school children, and To give suggestions to reduce parental and teachers' anxiety regarding school children's actual learning.

\section{Operational definitions}

Actual learning: Actual learning is the retention of knowledge gained during the online teachinglearning process.

Parental anxiety: Parental anxiety is the felt anxiety perceived by the parents regarding their child's education.

Teachers' anxiety: Teacher's anxiety is the felt anxiety perceived by the teachers regarding their students' education.

Parent: Parent is either mother or father, as only one parent was interviewed.

School going children and students have been used interchangeably in this paper.

\section{METHODOLOGY}

This research investigated the parental and teachers' anxiety with regard to actual learning getting transacted through online teaching-learning mode among school children during COVID-19 pandemic lockdown. The sample was selected from the state Himachal Pradesh, India from school teachers and parents of school children who used the online teaching-learning method during the COVID-19 pandemic lockdown. The data was collected with the help of snowball method for selecting the respondents. A 
total 53 respondents were selected of which 25 respondents were teachers and 28 respondents were parents from Himachal Pradesh, India. This study used focussed telephonic interview method for data collection. In-depth interview was held telephonically, after developing rapport and fixing up time for the interview. Apart from primary data collection, data was collected from secondary sources as well. The data based on the focussed interviews was analysed using thematic groupings. The human decision-making process is a cognitive process of choice among alternatives [6],[7], [8]. It means that the decision-making process is bounded by the human cognition constraints, and automating the thematic grouping of information facilitates the decision-making process [8]. This study used a semi-structured interview schedule for data collection.

\section{RESULTS AND DISCUSSION}

\section{Demographic Profile of the respondents}

Parent of school going children were selected, ranging from primary school to high school. Parents from varied socio-economic backgrounds participated in the study ranging from daily worker to middle class. Most of the parents were educated.

\section{Objective 1: To ascertain the need for online teaching-learning process}

In the present scenario, with COVID-19 pandemic lockdowns, closure of schools, continuing education through distance with the help of online teaching-learning process emerged as the only pragmatic alternative. Thus, online education had become basic need for the education system. Though distance learning and online education received absolute focus in the present context, distance education at the school level existed earlier as well. The Central Board of Secondary Education (CBSE), in 1979, set up an Open School at the secondary level for the learners of 14 years age, and above, who were unable to continue their studies in formal schools [9]. In November 1989, the Ministry of Education, Government of India, set up the National Open School, and amalgamated with it the Open School established by CBSE [10]. In July 2002, the nomenclature of National Open School was changed to the National Institute of Open Schooling (NIOS) [10]. The mandate of NIOS is to provide relevant continuing education at school stage to the out-of-school children. While open and distance learning had been on the horizon in a substantive way for quite some time, online education came to the fore comparatively recently. Studies [11], [12] have observed that with the help of online courses, students get more clarity on their subject or topic. Online teaching and learning have become widespread with the development of the internet and new technologies.

\section{Education during the lockdown in the COVID-19 pandemic time}

India, like the rest of the world, has relied upon the online education from school level to university level in this COVID-19 pandemic lockdown. Every state government of India has tried to give online 
education to all students from school students to university students. So, in this time to engage the student's online education has become an alternate to continue the education process. There was consensus among parents and teachers that in the pandemic scenario, distance and online education was the only pragmatic mode for the continuation of the school children's educational process, since going to school to study in the classroom through face-to-face mode was not viable.

The Ministry of Human Resource Development (MHRD), released a statement on March 21, 2020, and shared numerous free interactive e-learning platforms that allow students to continue their learning during school closures due on COVID-19 [9], which are listed below:

The DIKSHA platform provides e-learning material to the students, teachers and parents. It also provides video lessons, worksheets, textbooks and assessments. This app is available offline to use [9].

E-PATHSHALA is also an e-learning software in multiple languages with audio-video, books, etc. for classes 1-12 [9].

National Repository of Open Educational Resources (NROER) provides resources in multiple languages for classes 1-12 like books, interactive modules and videos [9].

SWAYAM provides videos, assignments, tests and credit transfers, for class 9 to 12 and undergraduate and postgraduate levels [9].

SWAYAM PRABHA is a Direct to Home (DTH) channels network. Telecast of educational programmes is available nationwide. Schedules can be found on the website for television shows as well as archived programmes [9].

All above portals depend on technology, and have to be used with the help of laptop, computer, android phones, tablets etc.

\section{Education in Himachal Pradesh}

Himachal Pradesh has one of India's highest literacy rates [13]. The Literacy rate of Himachal Pradesh is 82.80 percent as per the 2011 population census. Male literacy stands at 89.53 percent while female literacy is at 75.93 percent (2011 population census) [13]. Hamirpur district has top literacy rates in comparison to the other district of India [13]. In Himachal Pradesh, there are 10483 primary schools, 1056 middle schools, 1339 Secondary / Higher secondary schools, 64 General colleges 25 medical colleges ,01 Homoeopathic medical colleges, 187 Engineering, 16 Universities, 30176 S.S.I. Units [13]. During the time of COVID-19 pandemic lockdown, school education in Himachal Pradesh also used technology for teaching and learning through distance. Teachers also used new technology like internet projector, audio-video aid, etc. to make teaching effective and attractive for school children.

\section{School Education during COVID -19 in Himachal Pradesh}

On March 23, 2020 chief minister of Himachal Pradesh announced the curfew in all the districts of Himachal Pradesh due to the increasing number of corona positive patients. Therefore, all the educational 
institutions got closed in Himachal Pradesh till 14th April 2020 [13]. Again, due to increased number of cases of COVID- 19, the Himachal Pradesh government extended lockdown to $3^{\text {rd }}$ May 2020 and all educational institutions remain closed. In phase 3, lockdown extended to $17^{\text {th }}$ May and after that again extended to $31^{\text {st }}$ May 2020. During these phases, government of Himachal Pradesh ordered teachers to take classes online during this pandemic lockdown time. Teachers took classes from home with the help of technology following distance education [3].

\section{Objective 2: To examine teachers' anxiety regarding the actual learning that takes through online teaching-learning process among school children}

\section{Use of technology}

It was found that teachers used mobile phones to teach the students and students also used mobile technology to complete the teaching-learning process. Online learning was very useful, and helpful at this time because it is easily accessible and available all the time. In online learning learner used internet with technology to connect virtually with fellow learners and teachers [14]. Teachers informed that for sending teaching material they mostly used WhatsApp. Teachers made short video on the topic and sent it to the students with the help of the mobile phone, laptop, etc. Some teachers taught the students through online video conferencing. Teachers also took the unit test and gave assignment online to evaluate the students. Some teachers informed that for some academic topics it was interesting to prepare short and attractive videos for students but it was not possible for every lesson or topic.

\section{Teaching children with special needs}

Some teachers informed that it was impossible to teach all the students online especially children with special needs. These teachers reported that the children with special needs were not skilful in using technology. Teachers also stated that online teaching-learning technology cannot be used to teach students with special needs and disabilities, because they need special care and attention.

\section{One way mode of teaching}

Most of the teachers informed that online education is a one-way communication with children, as due to internet limitations, interaction directly with students was not possible.

\section{Internet connections and electricity}

The teachers informed that as it is well known for online education, we need internet connectivity, so this was the major problem to teach students with the online system due to poor network connectivity. Most of the teachers stated that due to poor internet connectivity it was impossible to teach students. Due to lack of internet, sometimes teachers could not complete their online teaching process and it created anxiety. Lack of internet connectivity at the students' end also led to a feeling of helplessness and 
anxiety, as the concentration of teacher and students breaks down. This results into teachers as well as parents feeling anxious and concerned about the actual learning taking place among the school students.

\section{Cost}

Teachers informed that some students were unable to afford the net connection due to cost. Some students did not have an android phone or computer or laptop, therefore, it was impossible to teach them online. Children from poor families could not afford the cost of internet, which created a problem for teachers as well as students as to how they would complete their teaching-learning process during COVID-19. This was another reason of anxiety among the teachers regarding actual learning taking place among the students.

\section{Time-consuming}

Teachers informed that it was very difficult to teach the whole class at a time when all students at a time were placed at a distance and the whole experience was different; almost alien. A few teachers informed that it became 'panic work' for them and made them anxious. Most of the teachers said that for some topics, online teaching-learning video and other online material 'helped students a lot' and made teaching-learning process very attractive, with students taking part 'very interestingly', but it took more time, and it became tough to make videos or worksheets for every student and every class. So, it takes lots of time for a teacher as well as students. At the primary level, teachers reported that it becomes more difficult as compared to higher classes, because primary students were not able to operate android phones and laptops, etc. Teachers reported that it was difficult and time consuming to teach young children who do not know how to use mobile phones, and difficult to teach them through distance or online education. The teachers also shared that it was not possible to teach all the curriculum/ lessons with an online platform especially in a language subject.

\section{Reliability of assignment submitted}

Teachers also shared that assignments work was easy to give using WhatsApp but reliability of students' answers was not trustful. This resulted in teacher's anxiety about the actual learning among school children.

\section{Discipline}

Teachers reported that in an online class student cannot learn discipline, and school needs to teach discipline for their future. Secondary students also skip their classes sometime.

\section{Health Issue}

Teachers also shared that complete dependence on online teaching-learning with phone and other technology negatively affects the student's health, and opined that 'online teaching-learning can help 
in academics but not in physical process' and 'all-around development of children cannot take place with online teaching-learning'.

Objective 3: To examine parental anxiety regarding the actual learning that takes through online teaching-learning process among school children

\section{Use of technology}

Some parents informed that due to COVID pandemic lockdown, they were expected to take over the role of teacher at home as well as support the family by doing work from home, which has resulted in a lot of strain. It was observed that parents whose children were studying at primary level were expected to contribute more towards their child's education, sit with the child in the online class, and explain the lesson to their child. The students of the primary school also needed their parents to help them operate android mobile phone and/or laptop at the time of class. Many parents, especially mothers, informed that at times 'it creates problem for them because they also need to perform their household duties', and they also 'feel anxious about their children's education'. In some cases, parents informed that 'they also did not know how to operate different educational apps' and they feel 'poor' in front of their child. A few parents, who were not much educated, informed that when teachers assigned some work from books, at that time they were 'not able to find solutions of the problems making them feel anxious and helpless.'

\section{Teaching children with special needs}

Parents of children with special needs informed that lockdown has a major effect on their child's growth and development and looking after their child during the lockdown has brought in a lot of anxiety among them and at times, they had felt helpless in taking care of their child's needs. Parents also informed that after initial few days, their children 'enjoyed the online teaching-learning.'

\section{One way mode of teaching}

Some parents felt that this mode of education was only one way teaching, and involvement of the student was limited. Some parents of high school students also reported that they found 'their child was physically showing presence in the online class but was actually at times eating or in washroom'. This had led to concerns in the parents regarding actual learning that would take place among their children.

\section{Internet connections and electricity}

Some parents said that they had limited or poor internet connectivity, and consequently, their child is unable to complete the class properly. This problem also created anxiety in parents about their child's education. 


\section{Cost}

It was observed that some parents whose income was affected due to lockdown expressed inability to buy android mobile phones, while some found the cost of internet connection quite high. This had resulted in the parents feeling anxious regarding their child's actual learning.

\section{Time-consuming}

Parents of primary school students informed that young children needed some adult to sit with them, understand the teacher's instructions during the online teaching-learning process and help them learn. Parents with limited resources, and those who are less educated felt that this type of education is widening the gap among children during the lockdown.

\section{Enhanced parent-child bonding}

Parents also informed that this online teaching-learning process has led to a new bonding with their child. Parents informed that both quantity and quality of time spent with their child had increased. However, they expressed concerns with regard to actual learning that would be taking place.

\section{Working on assignment}

Parents said since they were not with their child in the online class all the time, hence, they were not sure about the trustworthiness of assignments submitted by their children. Some parents informed that due to their own household, farming and other work commitments, they could not spend enough time to stay with their child online and attend their classes, especially with the primary school child.

\section{Discipline}

Parents informed that due to closedown of schools, children do not get up timely and proper discipline for study cannot be created at home.

\section{Health Issue}

Parents expressed concern over the health of their children. They informed that children continued to play games on their mobiles at the time of class and after class. They also expressed concern that continued use of phone and laptop could create health issues and physical fitness issues in the children.

\section{Objective 4: To determine the felt constraints in the online teaching-learning process with school children}

It was observed that teachers were taking online classes during COVID-19 pandemic lockdown with the help of mobile phone and laptops. Teachers commonly used WhatsApp, Google Meet, Zoom app for 
online classes. Sometimes teachers made short videos on the topic or content and sent them to students on electronic devices. Teachers commented that it made teaching-learning more interesting. Online learning was child centred. However, several constraints were also observed. Essentially, to transact this online teaching-learning process, both child and teacher require hardware like computer or desktop, laptop or mobile phone and as well as electricity and internet connection. Without these devices, online teaching-learning process cannot take place. Further, teachers teach directly from their home to children not in classroom but through technology to their home. Limited skills in use of technology for teaching among teachers and scarcity of on the job learning of use of technology for teaching, particularly in the early stages of lockdown, brought constraints in the online teaching-learning process. Both teachers and parents informed that students were fast at learning new technology compared to themselves. It was observed that in conventional education at school level, teachers used computer and internet as teaching aids for giving more clarity of any concept or topic, make the teaching-learning a more joyful experience for students. But in distance education technology was used as an instructional way to teach or guide the students to complete their studies. It was found that in lockdown, students spent less time in learning process as compared to when schools were open. Many students at home may feel stressed and this may negatively affect their ability to concentrate on schoolwork in the pandemic time. The lack of classroom, face to face contact, may cause students to experience less motivation in learning activities [3]. Transferring from offline to online learning has negatively affected primary and lower secondary school students from lower socio-economic status, who faced difficulties in obtaining the necessary hardware and technology and adapting to the new learning environment. This change created educational inequalities, because every student does not have similar background. Some families simply cannot afford android phone, laptop, internet etc. for the child's online learning. And this creates a problem for parents as well as teachers. While parents struggle with how they may afford all above things for their child to continue their education in this pandemic time, the teacher faces the challenge of how to connect with these students to educate them equally with those children who are having such devices. At home, parents are required to help the children in their school work especially at primary level, because they are not able to operate phone and other technologies on their own. Parents themselves not being conversant with the devices and technologies is also a major perceived constraint.

\section{Objective 5: To give suggestions to reduce parental and teachers' anxiety regarding school children's actual learning}

During this COVID-19 pandemic lockdown, online education was the only option to continue the teaching-learning process for imparting education and keeping school children gainfully engaged while maintain social distancing. So, all learners and teachers followed online education during this pandemic time. At this time of crisis, it was observed that all the school teachers, school children and their respective parents accepted the online teaching-learning. In many cases parents with limited resources also were seen purchasing android mobile for their child's education. 


\section{Suggestions}

Online learning was found to be the best way of teaching-learning during this crucial time as:

Students can acquire knowledge at home following social distancing.

It provides highly effective teaching-learning environment for studying.

It provides complete learning support to the students and allows students to learn 24/7 and learn at their own pace.

Online learning provides flexible time schedule to young children.

Therefore:

Government should ensure digital equity.

Children should practice use of technology for learning purposes.

Teachers, parents and students all should be involved in planning the daily and weekly schedule for children.

Children should establish a daily schedule/ time-table.

Teachers should develop lesson plan as done for face-to-face school classroom teaching.

Government/educational institutions should plan a policy which provides free internet and digital devices to all students, to promote online learning, as a result of which people will become engaged during the lockdown process and remain healthy during the pandemic.

At the same time, online teaching-learning process presents challenges for students, teachers and parents. Teachers have to teach student etiquettes for attending online classes, and parents have to keep a watch on their child's online behaviour, on the WhatsApp group and other social media being used by the school or teachers or peer groups. Bullying online has to be restrained. To make online education successful, we need technology and then internet as well as skills to use it effectively.

\section{CONCLUSION}

Online teaching-learning has tremendous potential, but it is also fraught with constraints and limitations, posing a unique set of challenges. These create anxiety for both parents and teachers. As observed from the above discussion, both parents and teachers have concern and anxiety regarding their child's achievement in terms of actual learning. We can conclude that online education is the most viable alternative when schools are shutdown to best continue the education process in the present pandemic situation. However, online education was observed to be not equally beneficial for all levels of students due to economic inequality. This inequality, apart from the various other constraints, creates stress and anxiety in both parents and teachers concerned for their child/student, particularly in the context of their actual learning. 


\section{Limitations}

The results of the present study are from primary and high school teachers and parents of school going children of Himachal Pradesh. During pandemic, due to limited resources, only a limited sample was contacted, and thus generalization of the results may not be possible. Use of online education in conventional mode of school teaching-learning during this pandemic time became the first choice for all institutions while following social distancing. Data obtained at a more macro level would be beneficial. Further, reasons for anxiety may require further assessment as COVID-19 pandemic had aggravated mental health issues in the general population.

\section{REFERENCES}

1. https://www.pharmaceutical-technology.com/news/who-declares-covid-19-pandemic

2. Https://www.medicalnewstoday.com/articles/coronavirus-causes\#transmission

3. Di Pietro, G., Biagi, F., Costa, P., Karpiński, Z. and Mazza, J. 2020. The likely impact of COVID-19 on education: Reflections based on the existing literature and recent international datasets (Vol. 30275). Publications Office of the European Union.

4. Https://voiceofbalochistan.pk/opinions-and-articles/healtheducation/role-of-education-in-national-development/

5. Https://www.indiatoday.in/education-today/featurephilia/story/covid-19-lockdown-impact-global-pandemic-oneducation-sector-1698391-2020-07-08

6. Anshakov, O.M. and Gergely, O.M.T. 2010. Cognitive Reasoning: A Formal Approach, $1^{\text {st }}$ ed. Berlin, Germany: Springer Berlin Heidelberg.

7. Hastie, R. and Dawes, R.M. 2010. Rational Choice in an Uncertain World: The Psychology of Judgment and Decision Making, $2^{\text {nd }}$ ed. California, USA: SAGE Publications.

8. Pinheiro, W., Fernandes, R. and Souza, L. 2016. Thematic grouping for messages in major events. International Journal of Information Systems and Project Management, 4(4): 51-65.

9. Jena, P.K. 2020. Online learning during lockdown period for COVID-19 in India. International Journal of Multidisciplinary Educational Research (IJMER), 9(5): 8.

10. https://www.nios.ac.in/about-us/profile.aspx

11. Lin, C.H. and Zheng, B. 2015. Teaching practices and teacher perceptions in online world language courses. Journal of Online Learning Research, 1(3): 275-303.

12. Panda, S., Venkaiah V., Garg, S. and Puranik, C. 2005. Tracing the Historical Developments in Open and Distance Education. Four Decades of Distance Education in India, edited by Suresh Garg, V. Venkaiah, Chambi Puranik, and Santosh Panda, Viva Books Private Limited: New Delhi, India, pp. 3-23.

13. Https://en.wikipedia.org/wiki/Education_in_Himachal_Pradesh\#: :text=Himachal\%20Pradesh\%20was\%20 under $\% 20$ the,to $\% 20 \mathrm{a} \% 20$ considerably $\% 20$ high $\% 20$ level.

14. Https://www.worldbank.org/en/topic/edutech/brief/how-countries-are-using-edtech-to-support-remote-learningduring-the-covid-19-pandemic 